\title{
Musical Parody of Acapella Mataraman: A Creativity Compromise for the Performing Arts Market in Yogyalkarta
}

\section{Firmansah}

Mercu Buana University

\begin{abstract}
This study aims to identify and understand the creative process of artists in the performing arts market. The concept of creativity is often the response of the high degree of creativity. Basically an assumption appears if the artist is able to survive in the market is the result of creativity in the performing arts is a form of alternative or compromise. This phenomenon occurred in the group Acapella Mataraman. This case study is based on the concept of Jennifer Lindsay and Umar Kayam about the existence of performing arts groups. The primary data are gained from the interview process with Pardiman Djoyonegoro, then, it is completed with the secondary data through a focus group discussion to explore deeper about creativity process on Acapella Mataraman. The results show that the repertoire of pangkur jenggleng and emperan Nuswantara is a form of compromise. Musical sounds and rhythms of modern music elaborated and presented through acapella techniques.

Supplemented by the concept of parody that has appeal and value to the consumer tastes of the performing arts. This form is an effective medium for the delivery of criticism and moral content on each of the repertoire.
\end{abstract}

Keywords: creativity compromise, performing arts market, pangkurjenggleng, emperannuswantara and acapella mataraman

\section{INTRODUCTION}

Yogyakarta is one area in Indonesia which is known as a city of culture. In this city also there are plenty of activities for the performing arts do have a lot of individual creative and performing arts groups. Some groups such as: KUA Etnika, Hip Hop foundati, Puppet Hip Hop, and Acapella Mataraman. Each of these groups have in common is creativity by elaborating traditional and modern elements in the form of a musical. But attention is Acapella Mataraman because it has characteristics as a differentiator from other groups in the performing arts market arena.

The repertoire through genres of musical parody of Acapella Mataraman is the result of creativity Pardiman Djoyonegoro as a major figure. He was known as a skilled artist imitating the sound of musical instruments through acapella techniques and elaborated with local cultural elements are then presented with a humorous style. For decades, the genre was maintained and became unique to this group. The use of such genres as the value 
of the watch allows the consumer to use his services frequently performing arts to entertain in a variety of events. Most of the play at the position at the end of the show so that viewers are willing to wait long to see his performance.

Starting from the uniqueness of it, the writer interested to study musical parody group Acapella Mataraman. The existence of the group comes from the creativity Pardiman Djoyonegoro as the main figure to see opportunities in the performing arts market. The assumption appears that the possibility of creativity is one form of compromise or alternative. Indirectly, this allows the group's repertoire is kitsch art that is only concerned with economic factors - or kitsch or art popular in Mataraman Acapella has a different meaning and not just economic factors.

\section{Creativity Compromise}

Creativity compromise is a form of strategy for the artists or performing arts groups to persist in the performing arts market. According to Kayam (in Lindsay, 1991) for the existence of kitch or commercial art, a way of presenting must actively changing according to the times in which he exists. This is useful in order that the work of art to be popular and attracted the attention of the audience for making money in order to stay alive.

Than, in the opinion of Khayyam (1997) the context of Indonesia is currently in popular culture where the situation was still very fluid, bound with traditional culture, the tendency of people to consume foreign cultures was through commercialism dictation. Basically, the popular music composition of course, the simplicity was the main thing for the purpose of easily understood or enjoyed by consumers.

The simplicity was found in the musical compositions with periodization or phrasering, the harmony structure was built relatively easy, rhythm repeated, short in duration and without more expansive processing (Mack, 2012). Likewise the song forms uses general forms that is A-B (binary) - the two parts or ternary form (A-B-A ') wherein A is theme and beggining period, $\mathrm{B}$ is the contrast period, and $\mathrm{A}^{\prime}$ is a recapitulation. This can be described as a musical proximity (listener habitus) of the general public.

When referring to both opinion, in order to get the exchange against the spectacle rate, the repertoire of Acapella Mataraman has the simplicity in form to make it popular. In order tosee the simplicity of form, The Pangkur Jenggleng reperotar had been chosen because according to Pardiman Djoyonegoro it is a representation of Acapella Mataraman. In addition, a new third-generation repertoire which was often played together with Jenggleng Pangkur that is Emperan Nuswantara had also been analyzed.

In Emperan Nuswantara repertoire, melody or rhythm can be seen as follows: 


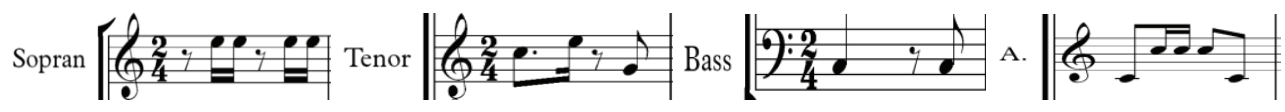

Figure 1. Melody and rhythm of EmperanNuswantara repertoire

Soprano as vocal and sometimes imitating the sound of the guitar, alto also imitate the sound of the guitar, tenor imitating the sound of ketipung but still use the tone and bass sounds to imitate the sound of a bass guitar. The intro rhythm on soprano and made repeatedly by the placement of tone E statically. In Alto the rhythm is repeatedly sounded acted with the tone C-C1. Likewise also the bass acts as a companion with a simple rhythm pattern by placing on the tone $\mathrm{C}$ area. The tone was sounded repeatedly. Then in the tenor voice, the rhythm pattern was somewhat enlarged with a tone composition of C1, E1, F as decomposed. The use of that rhythm gives the feel of dangdut music in this rereptoar. At bar 10 in the tenors was found a first interpellation to mark the same phrase. However, the rhythm and melody on soprano voice then developed with a previous rhythm pattern. Second interpellation on the soprano voice in bar 22 and 26 interpellations are as follows:

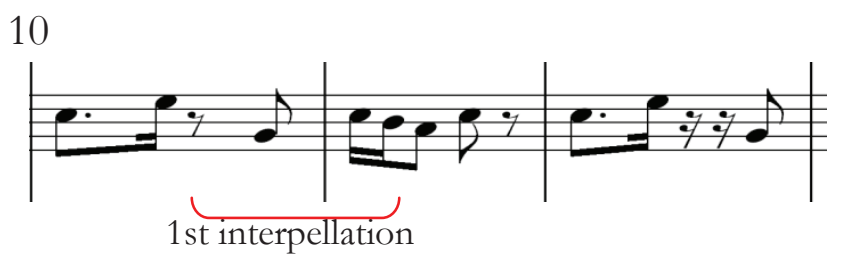

Figure 2. 1st interpellation of EmperanNuswantara repertoire

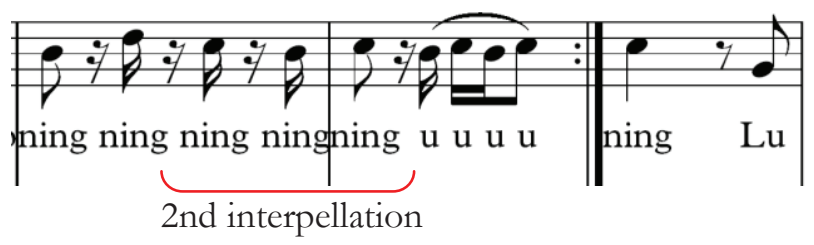

Figure 3. 2nd interpellation of Emperan Nuswantara

Interpellation on both of bar 26 above was used as a cue for the entry of lyrics with a simple rhythm and melody pattern:

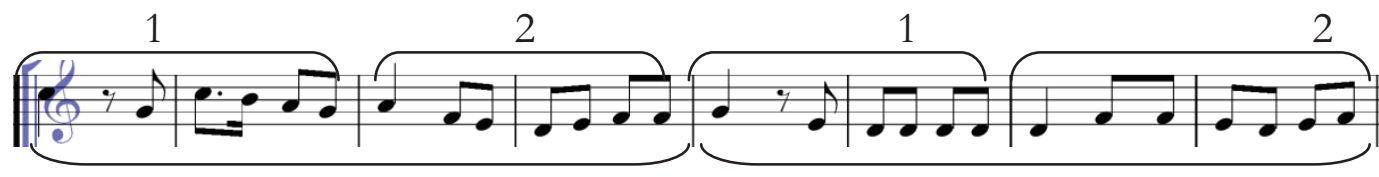

Frase I

Frase II

Figure 4. Phrase 1 and 2 in the rhythm and melody pattern of EmperanNuswantara 
The rhythm of the song was made in a simple symmetrical form. This can be seen in the first phrase where there are two different motifs. In the second phrase there are also different patterns of motif but the motif is the same as the first phrase. But in the second phrase, the melody occupies different locations as in the picture above. Overall, when listening to Emperan Nuswantara it creates the impression of dangdut music. Then, in the Pangkur Jenggleng tune at the opening comes a Manyura phatet. Furthermore, there is a significant change that is using rap music. The rhythm pattern is fairly simple, played continuously and repeatedly. However, it is sometimes interspersed with the sound of beat box different from before. For example, sometimes imitating the sound of a drum set and then varied by imitation sound of a DJ (disc jokey). The rhythmic pattern used in beat box was as follows:

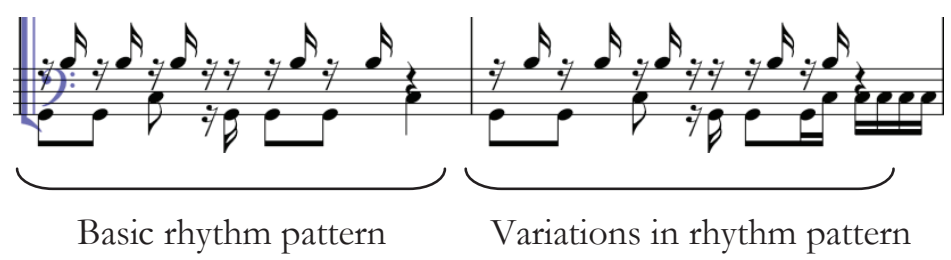

Figure 5. Basic rhythm pattern of beatbox and repertoire variations of Pangkur Jenggleng

Wherewith the melody, rhythm patterns of the melody was created with the expansion of the rhythm in bar 4, 5 and 7, which are marked by a red line. It seemed that this was to to avoid the impression of monotony in the song. But the variation is not enough transformed drasticly and developed quite simple. Melody of the song was also only played in tone $\mathrm{E}, \mathrm{F}$ \# and $\mathrm{G}$. It can be seen in the image below:
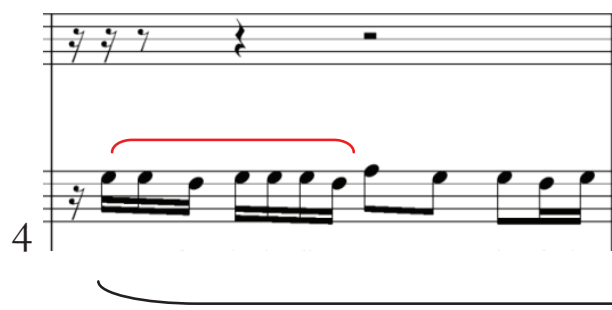

5

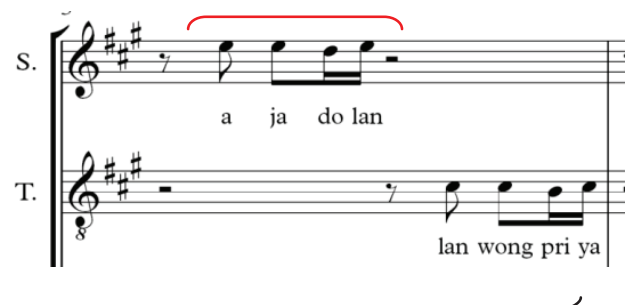

Phrase I

Figure 6. Rhythm pattern of melody, phrase I of Pangkur Jenggleng 


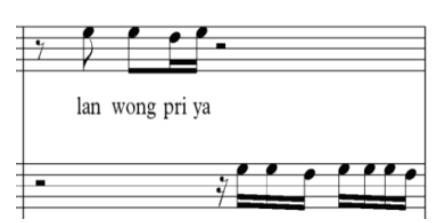

6
7

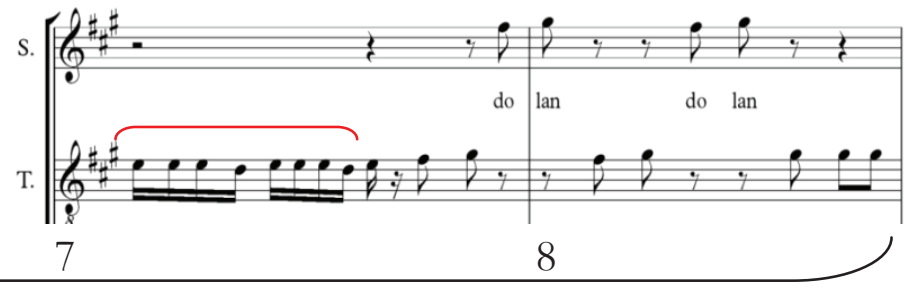

Phrase II

Figure 7. Rhythm pattern of melody, phrase II of Pangkur

Analysis results of the second form of Acapella Mataraman repertoire has the simplicity in form that made it to be is said as the kitsch art or pop music. There is a standardized pattern as it follows the popular music namely rap and dangdut. This is also confirmed by the opinion of Mack (1995) that popular music is more simple, has a standardization and more want to satisfy the audience for commercial purposes.

Although both of the repertoire belongs to popular music types, but there is a difference in the Emperanin Nuswantara. It has the Indonesian impression in lyrics and musical forms. What is meant here about the Indonesian in the form of music was the sound of dangdut music that was presented in the tenor's rhythm pattern:

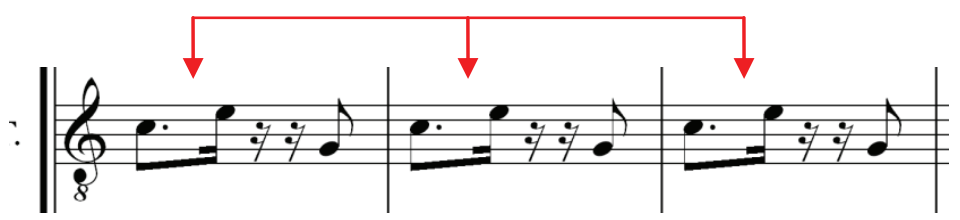

Figure 8. strong accent/syncope on tenor rhythm

According to Frederick (Ibrahim, 1997) and Wientraub (2010) dangdut music is a popular music of Indonesia. Being a political media to construct public taste in music. Indeed EmperanNuswantara was not a dangdut piece but a musical parody genre known as hybrid art. So it is possible that impressions of other genres of music in the repertoire occurs. However, on both opinions and the dangdut impression that was presented Pardiman Djoyonegoro in the Emperan Nuswantara, was found fundamental matters. That is, the characteristics of Indonesian pop music was that the strong accent was on the light part or syncope (marked with a red line). This basic rhythmic pattern was occured on the opening and on the way the sounds are parsed into three lines, the alto, tenor and bass.

According Khayyam (1997) in the era of globalization, popular music runs parallel to the orientation of Indonesian contemporary cultural and urban masses especially the young generation and liberal economic system with an orientation toward mass consumerism. It 
can be found under Acapella Mataraman that was the standardization of repertoire forms. On the concept of Attali (1985), especially in music performance it was regarded as a representation. It was intended to use the value of spectacle involving the exchange and harmony. Surrounded by concerned parties for political and economic purposes. In the exchange, was the entrenched capitalist economic system with the loss of the musicians. While in the harmony is the construction of the dominant party, such as what kind of music deserves to gain spectacle value.

According to the concept of Kayam and Attali, it is known that in Emperan Nuswantara repertoire lies a characteristics of Indonesian pop music in terms of accent. There was an economic and political objectives that were not awared, the use of the rhythm by Pardiman Djoyonegoro indicates that this repertoire is devoted to commercial and political purposes that was easily enjoyed by viewers/listeners besides that there were loads of criticism and ideology of Nuswantara. But there is a difference to the concept of Attali that emphasizes harmony in the intra musical and then linked it to politics and economy. The intra musical emphasis of Emperan Nuswantara that presents the characteristics of Indonesian pop music was on its accents. These characteristics was the representation of the political and economic phenomena in the field of music in Indonesia.

In accordance with the opinion of Khayyam and Piliang (2003) on parody, it can be said that the reason of Pardiman Djoyonegoro remaining to stay on the genre of musical parody besides the commodity medium, as well as an effective medium to transfer content works of social criticism or 'ideology of Nuswantara'.

This repertoire as a representation to Acapella Mataraman. This can be seen through the reasons in following the era when presenting the repertoire. This means that the characteristics of pop music was intended for the young people in either music and the lyrics. In addition to the economic side, there is a moral message because he thinks that in popular culture the large media industry presents entertainment without moral message content and gave birth to promiscuity. Teens also tend to prefer popular music (west) to gamelan music. From here then made a musical interpretation in a musical parody genre with a solid beat pattern (rap) and a humorous poetry. To deliver the moral message for teens through philosophy of Javanese culture using popular music.

The lyrics of this song is a representation of Pardiman desire ${ }^{i}$ that is to return to the state of Indonesia which was safe and secure. Same with Pangkur Jenggleng repertoire, the Emperan Nuswantara was also originated from 'Nuswantara ideology' as a message for the current generation to appreciate what have been passed down by generations ago. This analysis found an understanding that the economy has a role in the form of repertoire presentation of Acapella Mataraman. The form in which significantly change the aspect of performance supporters such as the number of players, the artistic properties and costumes. While in the 
music, it carries popular music, editing the repertoire appropriate to the allocation of time given by the consumer and use the Indoneisan characteristics in pop music.

\section{Acapella Mataraman Existence in the Performing Arts Market}

In accordance with the concept of Khayyam (1991), for the existence of commercial art or kitsch such as Acapella Mataraman must posses the use of the value of the show with a change in the form of presentation. Two previous repertoire became a representation of the use of the value of a show for the exchange of economic currents, had a harmony between the intramusical and extramusical that is following the public taste. These two repertoires were presented with the musicalparody genre combined between music, dance and theater in nuance of humor.

Creative services in the performing arts cannot be done individually. So in the interaction between the economy and production, there are some aspects to be taken into consideration that was adjusted by the amount of players, artistic property, stage location distance, demand on new work requests and the segmentation. The interaction between these two factors were also that promote changes in the form of presentation. Changes in the form of presentation currently was significantly on the number of players, costumes and use of choreography. Regarding the music, it was still presented using parody musical genre with pieces of repertoire used according to the allocated time of performance given by the consumer.

Business services in the show was run with an applied strategy such as segmentation expansion and creations of trinkets. It is also based on a consideration of the marginal cost and marginal benefit. The marginal costs was normally issued when consumers was of the middle down economiy. The fee was to cover the salary of players as a result of the cost of production was sometimes not enough to be allocated to the items of production. But the profits was obtained through that strategy, because through the expansion of segmentation it will also be a promotional event that increased popularity to enable a marginal profit. This also applies to the provision of trinkets to balance between the cost and marginal profits.

Besides the economic side, the implementation of segmentation strategy was also based on an institution or institutional arround Pardiman Djoyonegoro. Where the values, norms, habits, culture, were all reflected in the economic activities done. The other side of implemeting segmentation was intended so every people can enjoy the work. Either as appreciators or just lovers. In general, the purpose behind such enjoyment is the delivery of criticism content and moral message to the community.

Each repertoire was a result of creativity with inspirations in every aspect of life which is 'ideology Nuswantara' until the socio-political events. The intrinsic motivation to cultivate it 
into a piece of music was derived from his experience in the music world both in academic and non-academic. Then from that creativity is able to generate economic income for the necessities of life.

Through this analysis can be obtained an understanding that parody and kitsch became one in the body of Acapella Mataraman, which lasted until today. Musical parody genre became the characteristic in the performing arts market. Through this characteristic it was considered to be an effective way to obtain the value of the show and the exchange of money. Moreover, followed by expectations that the criticism in the content of the repertoire can be delivered through the entertainment of the genre. This is the reason for Pardiman Djoyonegoro to remain in its genre. Changes in the form of presentation is not the only major factor that makes it able to survive in the market. But creativity makes this group has an existence for decades in the performing arts market.

\section{Musical Ideas}

Parodi has developed into a study in postmodernism to declare lowness of an art. Featherstone (in Smiers 2009) argues that this is one form of celebration of lowness of a culture. Obviously this leads to a problem of hybridity by the way through searching in history. Questioning the depth of a culture since ancient times whereas cultural diffusion has occurred and allows no more original culture.

Similarly, when speaking of music, Smiers $(2009 ; 185)$ gave some examples to underline that since the first it has occured a cultural crossbreeding. Along with the development of the era, when the music comes with some of the genre which marks the crossingbreeding sustainability. Musical parody became one of the many in the world. Today this becomes a kind of entertainment for public consumption.

Music and consumption become an interesting discussion event for the critics like Adorno and Horkheimer (Budiarto, 2001), and Benjamin (in Strinati, 2009). Commercial music in their view is a lost of aura and autonomy. When referring to this view it can be said that a parody musical genre has lost its aura and its autonomy. There is an element of commercialism and represents shallowness in culture.

However, this view is probably misleading to be accepted outright. There is another side to be built from the parody. According to Smiers (2009), hybridity should be known as a special purpose. There is an intention to bring it from experience in experiencing from their environment. Similarly disclosed by Piliang (2003) the effects of humor and absurd in a parody displayed in a manner by distorting or by making plesetan from the original, being ironicaly, critical, even by creating politically loaded and ideologically. Dialogue occurred in the parody will rise to a form of serious criticism, polemic, satire, debate, humor or jokes from the form already exist. 
Works of art, whatever the form been expressed will lead people into their human existence. Playing an important role in the contribution of development of personal and collective identity. From some of this opinion, observing the repertoire of Pardiman Djoyonegoro with its musical parody genre occured other elements outside the economy. In intramusical, using diatonic tones in popular music elaborated with the local culture elements. Of course there is an intention of its own why it is presented in the results of the creativity.

He stated that many elements of 'ideology Nuswantara' that characterizes his work. One of his works the PangkurJenggleng have an inspirational source from SeratWedhatama. It contains life guidelines for the community of Java in honouring the values of humanity and the local culture. Created since the KGPAA MANGKUNEGARA IV and according to Pardiman is still relevant to be a way of life for the present generation.

Criticism of the human condition today forgot its essence as a Nuswantara generation. Adopting foreign cultures without filtration to shape the behavior of harming people. Such as radical beliefs, freeculture and tolerant attitude that has been lost. When looking at the history, Indonesia since 1970 is indeed an urban society. Has been flooded with the commodity and culture based on the consumer culture of global capitalism (Foulcher, in Abraham, 1997). This is the underlying moral message in the content of Pangkur Jenggleng repertoire. Not just as an excuse, as every show always presented this repertoire. This is the reason other than the economy, there is a content of criticism and moral messages through the show of Acapella Mataraman.

Of the two earlier repertoire, although it was a popular music but not necessarily be stated to lose the aura of such expert opinion earlier. If it was stated as it means the Indonesian society then was a society that had lost the aura in the art. Especially when talking about EmperanNuswantara this means about Indonesian matter. Caused by the characteristics of Indonesian pop music lies in the rhythm pattern of Emperan Nuswantara. This can be clarified with the opinion of Lindsay (1991) on the popular arts. Whereas, traditional art that was said to be valuable also has been changed according to the existing demands - arts today comes from the arts of the past. So to say all kinds of music in Indonesia is fairly popular.

But it is clear that the elaboration of foreign culture and local culture in the parody musical genre, not only serve as a mass consumer entertainment but presents a moral message content. Pardiman used musical parody genre in entrepreneurial activity creating creative services. His creativity in cultivating imitation of the sound of a musical instrument was also becoming a major force in implementing its musical ideas. This is to make his works still enjoyed for entrepreneurs should be smart in public taste. Entering the popular culture 
track to earn money exchange. This was caused by popular music which was more accessible to the public and provide a role in critics in the assessment.

Commodities, moral message media, criticism and creativity within Pardiman produced musical ideas. It then becomes a repertoire that is demanded by the public audience. This is not a matter of losing the aura since until now Acapella Mataraman still exist through musical parody. This means that musical parody still has an aura both in criticism content and in commodities. Musical ideas created by Pardiman was proof that he had existence in the performing arts market.

1. The impression of dangdut music which was present in EmperanNuswantara implies that there was a political and economic content inside if seen in terms of intramusical. The political and economical purpose of dangdut music in extramusical has also been described by Frederic (Ibrahim, 1997) and Weintraub (2010).

2. Results of discussion between the author and (PD) on 'Nuswantara ideology'. The Glory and greatness of ancestors and their heritage. Foreign cultures entered and damaged the local culture. From this discussion, the author obtained data about what is represented on the works of AM. It is said that the curved like waves feature is a sign that the ancestors lived under the sea that is the Royal Queen of the South Coast. The temple is also said to be a magnificent park of the palace under the sea. According to him generations should find out about it because the 'install culture' (translated by author: a collective memory) that exist in each human mind. Because foreign cultures would be damaging if the generation was not aware about his true identity.

3. Ibid

4. Ibid

\section{REFERENCES}

Attali, Jaques. 1985. NOISE: The Political Economi of Music. Minniepolis: The University of Minnesota Press.

Budiarto, C Teguh. 2001. Musik Modern dan Ideologi Pasar. Yogyakarta: Tarawang Press.

Denzin, Norman K \& Lincoln Yvonna S. 2009. Handbook of Qualitative Reaserch. Yogyakarta: PustakaPelajar.

Hartono, Agustinus. 2007. Skizoanalisis Deleuze \& Guattari; Sebuah Pengantar Genealogi Hasrat. Yogyakarta: Jalasutra.

Ibrahim, Idi Subandy. 1997. Lifestyle Ecstasy: Kebudayaan Dalam Masyarakat Komoditas Indonesia. Yogyakarta: Jalasutra.

Lindsay, Jennifer. 1991. Klasik, Kitsch, Kontemporer: Sebuah Studi tentang Seni Pertunjukan Jawa. Yogyakarta: GadjahMada University Press.

Mark, Dieter. 1995. Apresiasi Musik: Musik Populer. Yogyakarta: Yayasan Pustaka Nusatama. . 2012. Ilmu Melodi, second printed. Yogyakarta: Pusat Musik Liturgi.

Piliang, Yasraf Amir. 2003. Hipersemiotika Tafsir Cultural Studies Atas Matinya Makna. Bandung: Jalasutra.

Smiers, Joost. 2009. Art Underpressure: Memperjuangkan Keanekaragaman Budaya di Era Globalisasi. Yogyakarta: Insist Press.

Strinati, Dominic. 2009. POPULER CULTURE: Pengantar Menuju Teori Budaya Populer. Yogyakarta: Ar-Ruzz Media Group.

Weintraub, Andrew N. 2010. Dangdut Stories: A Social and Musical History of Indonesia's Most Popular music. USA: Oxford University Press. 


\section{ATTACHMENT}

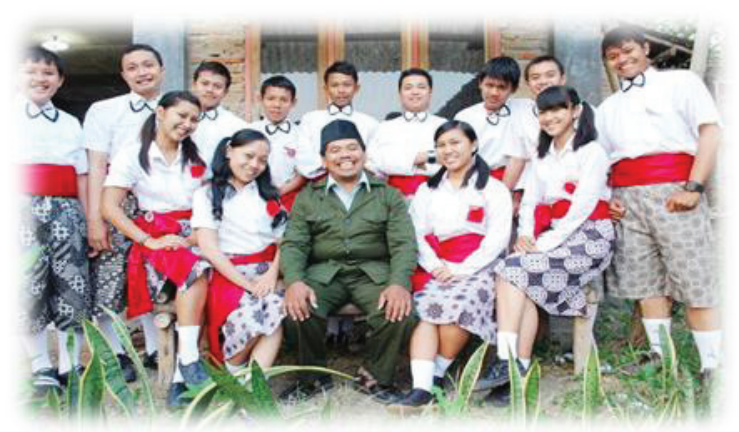

Pic 1. Members of Acapella Mataraman Group (Source: www.worldcangkem.com)

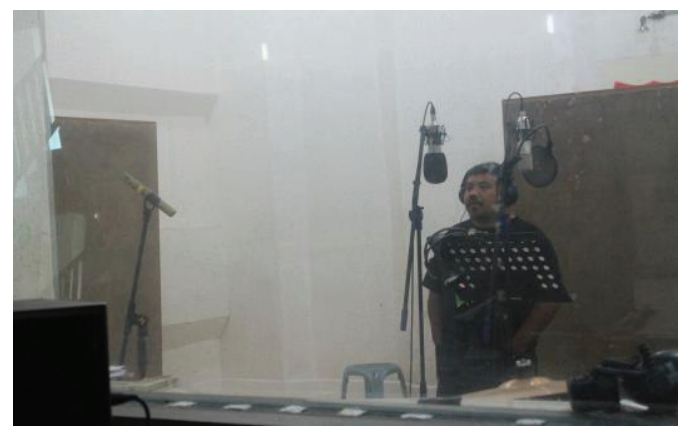

Pic.2 Pardiman Djoyonegoro (source: Firmansah's documentation)

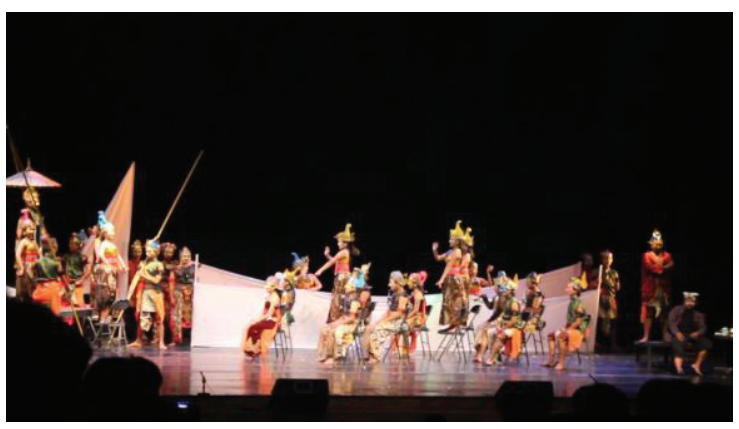

Pic.3. Performance of Acapella Mataraman (source: Firmansah's documentation) 